\title{
Screening of Fungi Isolates from Kaduna Refinery Effluent and Romi River and Their Potential for Bioremediation
}

\section{*1 OBUKOHWO, K; ${ }^{1}$ VANTSAWA, PA; ${ }^{1}$ DIBAL, DM; ${ }^{2}$ IJAH, UJJ; ${ }^{1}$ ONWUMERE, GB; ${ }^{1}$ NDIBE, TO}

\author{
${ }^{I}$ Department of Biological Sciences, Nigerian Defence Academy, Kaduna, Nigeria \\ ${ }^{2}$ Department of Microbiology, Federal University of Technology, Minna, Nigeria \\ *Corresponding Author Email: siena3684@gmail.com
}

\begin{abstract}
The operation of Kaduna Refinery and Petrochemical Company (KRPC) has increased effluent generation with consequent effects on water quality and habitat since it is discharged into nearby receiving water body. These effluents contain heavy metals and other toxicants. Samples were collected from the effluent discharge point of the Kaduna Refinery and Petrochemical Company (KRPC) and from Romi River located at Kaduna South Local Government Area of Kaduna state. Standard methods were used to analyze the physicochemical parameters and heavy metals of the effluents. A total of 14 fungi isolates were identified from the samples. These fungi isolates were screened for their bioremediation potential on some toxic components in refinery effluent and were identified using molecular techniques. Four fungi isolates (Chrysosporium tropicum, Aspergillus flavus, Aspergillus niger and Rhizopus oryzae) were selected for bioremediation. Carbon (IV) oxide evolution increased progressively during the period of bioremediation. There was a noticeable decline in the phenol, lead, cadmium and nickel in the entire bioremediation medium. There was a positive correlation between phenol and cadmium with a coefficient of 0.969 . Consortia of fungi isolated from the refinery effluent and Romi River samples were effective in the bioremediation of refinery effluent. The mixed consortium of four fungi showed the most efficacies in the bioremediation of refinery effluent in terms of phenol, oil and grease, cadmium, lead and cadmium reduction. Kaduna Refinery and Petrochemical Corporation (KRPC) should adopt bioremediation as one of the techniques in treating effluents before being discharged into receiving water bodies.
\end{abstract}

\section{DOI: https://dx.doi.org/10.4314/jasem.v24i9.25}

Copyright: Copyright (C) 2020 Obukohwo et al. This is an open access article distributed under the Creative Commons Attribution License (CCL), which permits unrestricted use, distribution, and reproduction in any medium, provided the original work is properly cited.

Dates: Received: 10 August 2020; Revised: 16 September 2020; Accepted: 22 September 2020

Keywords: Effluents, Fungi, heavy metal, bioremediation.

Environmental issues are of increasing concern in Nigeria, like other developing countries, because most industries discharge their wastewater without efficient treatment probably due to the high cost of existing treatment technologies and lack of strict enforcement of environmental laws. High concentration of pollutants present in discharged effluent could alter the distribution and composition of fauna and flora in the receiving water body. In some cases, this may result in total elimination of some species found in these waters (Gadd, 2010). Fishes harvested from polluted waters may be unsafe to eat as accumulation of some toxic metals in them renders them unfit for consumption (Basorun and Olamiju, 2013). Most farmers planting around Romi River, Kaduna utilize the discharged wastewater from refinery in the irrigation of their farms and it has been reported that certain trace elements such as lead, nickel and cadmium could accumulate in the soil and is absorbed by the plants. This could lead to major health and environmental problems along the food chain (Adenuga et al., 2006). Other components of refinery effluents such as phenols, aromatic hydrocarbons (benzene, toluene, ethylbenzene and xylene) are toxic and carcinogenic and could pose problem to the health of inhabitants of communities around the refinery and those using water contaminated by these compounds (Ugya et al., 2015). Industrial pollution stands out as a major problem facing the Nigeria society. Several agencies are being put in place by regulating bodies such as the National Environmental Standards and Regulations Enforcement Agency (NESREA) in Nigeria to ensure that industries all around the country comply with the standards set up by World Health Organization (WHO). These efforts are geared towards having a disease-free environment and the improvement of health standards for the populace. Effluents generated by industries remain a major source of industrial pollution. Control of environmental pollution is one of the prime concerns of society today particularly with affordable and effective methods. Therefore, bioremediation techniques are currently favoured because they are eco-friendly and cost-effective. In addition, bioremediation uses organisms which are 
cheap to obtain and it also reduces petroleum hydrocarbon in polluted sites with minimum site disturbance. Bioremediation relies on biological agents such as bacteria, fungi, algae, termite and plants, to reduce concentration of pollutants usually as contaminants of soil, water or sediments that otherwise threaten public health to an innocuous state (Mansur et al., 2003). Bioremediation is a pollution control technology that uses biological systems to catalyze the degradation of or transformation of various toxic chemicals to less harmful forms. The ability of microorganisms to transform a variety of chemicals has led to their use in bioremediation processes. A number of microorganisms have since been studied to unfold their degradative abilities in remediation of pollutants. Diverse fungi cultures have been investigated for bioremediation processes (Obire et al., 2008; Hadibarata and Tachibana, 2009). Fungi have been observed to perform better than bacteria in bioremediation by virtue of their aggressive growth, greater biomass production and extensive hyphal reach in the environment. Ashoka et al. (2002) stated that the high surface-to-cell ratio of filamentous fungi makes them better degraders under certain niches.

Mycoremediation is a form of bioremediation in which fungi-based technology is used to decontaminate the environment. Fungi are unique among microorganisms in that, they secrete a variety of extracellular enzymes of importance in bioremediation which is stimulated under nutrient deficient conditions (Okougbo et al., 2016). Fungi growth is also reasonably fast enough for application in bioremediation processes (Aust et al., 2003).

In addition to their ability to penetrate contaminating substrates, fungi are regarded as superior to bacteria in that they can grow under environmentally stressed conditions (low $\mathrm{pH}$ and poor nutrient status), where bacteria are expected to have limited bioactivity (Gadd, 2010). Fungi degradation rate of organic matter may proceed more rapidly than bacterial degradation, with complexation suggested as the main mechanism of calcium mobilization (Gadd, 2010).

Moreover, fungi can easily be transported, genetically engineered, and scaled up. Fungi cell walls and their components play a major role in biosorption of toxic compounds during wastewater treatment (Gadd, 2010). Need arises for alternative, cost-effective, environmental friendly cleaning technologies to replace physicochemical treatment methods since the latter is expensive, not environmentally friendly and does not lead to a complete purification of the wastewater.
Therefore, the main objective of this study was to screen fungi isolated from the Kaduna refinery effluent and Romi River with potential for bioremediation.

\section{MATERIALS AND METHODS}

Study Site: The site for this study was the Kaduna Refinery and Petrochemical Company (KRPC) discharge point located at Chikun Local Government Area of Kaduna State, Nigeria. The refinery occupies an area of 2.9 square kilometres and is located on an undulating land about 700 metres above sea level, as described by Machido et al. (2014).

The Romi River receives effluent from the petrochemicals and refinery waste treatment facilities. The river runs through Ungwan Romi village where there are human settlement, agriculture, industries and solid waste disposal sites. The river provides breeding ground for aquatic animals. It is also a source of water for drinking and recreational activities for the public and as a sink for industrial and domestic wastes.

Collection of Refinery Effluent and Water Samples from Romi River: Samples were collected from the effluent discharge point of the Kaduna Refinery and Petrochemical Company (KRPC) and from Romi River (Fig. 1). The samples were collected from four sampling points (A-D). Point A (point of exit from the refinery), Point B (point of entry into river), while water contaminated by effluent was collected from Romi River at a distance of 100 metres upstream (Point C) and 100 metres downstream (Point D). Samples were collected with a well-labeled (indicating the sample code, collection point, date and sampling time) sterile bottles in duplicates from each sampling points. After collection, samples were transported in ice-box to the Microbiology Laboratory of Ahmadu Bello University for microbial analysis.

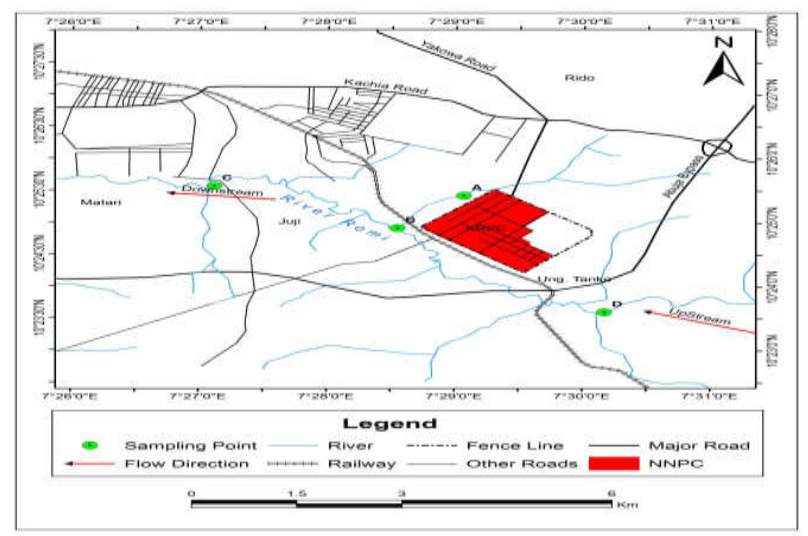

Fig.1: Part of Kaduna South Showing Study Sites and Various Sampling Points 
Isolation and Morphological Characterization of Fungi: The microbiological analysis of the samples was carried out following the method described by Machido et al. (2014). Nine millilitres (9ml) of each sample in duplicates was aseptically dispensed in sterile centrifuge tubes and centrifuged at a speed of $250 \mathrm{rpm}$ for 10 minutes to concentrate the samples. After decanting the supernatant, $0.1 \mathrm{ml}$ of the residue of each sample was spread-plated on sterile solidified laboratory prepared media made according to manufacturer's procedure (potato dextrose agar) in duplicates supplemented with $50 \quad \mu \mathrm{g} / 1$ of chloramphenicol to suppress bacterial growth using sterile glass rod. The plates were incubated at room temperature $\left(25 \pm 2^{\circ} \mathrm{C}\right)$ in a sterile cupboard for 5 days. Distinct colonies from incubated culture plates were assigned isolation codes; sub-cultured repeatedly and transferred aseptically into potato dextrose agar slants (as stock) for identification and further laboratory analysis. The pure isolates were maintained in agar slants and stored in a refrigerator. The colonies grown on the plates were counted and the result was expressed as colony forming units per milliliter of the sample $(\mathrm{cfu} / \mathrm{ml})$ using the formula below:

$$
C f u / m l=\frac{T N \times \mathrm{DF}}{V}
$$

Where $\mathrm{TN}=$ total number of colonies, $\mathrm{DF}=$ dilution factor and $\mathrm{V}$ - volume of inoculum

Following the procedure described by Thippeswamy et al. (2012), macro-morphological characteristics of the fungi isolates, such as colour of aerial and substrate mycelia, texture, of the fungi isolates were observed. Characteristics of the sexual reproductive structures, presence or absence of septa, presence of foot cells and chlamydospores were observed and recorded. Each fungal isolate was identified using appropriate taxonomic guide (Hakeem and Bhatnagar, 2010).

Screening of Fungi Isolates with Potential to Utilize Refinery Effluent: Fungi isolates were screened for their potential to utilize refinery effluent following the method described by Idowu and Ijah (2017). Each fungi isolate was inoculated into sterile potato dextrose broth (PDB) and incubated at room temperature $\left(25 \pm 2^{\circ} \mathrm{C}\right)$ for 48 hours. Mineral Salt Medium (MSM) used consist of $\mathrm{Na}_{2} \mathrm{HPO}_{4}(0.2 \mathrm{~g})$, $\mathrm{K}_{2} \mathrm{SO}_{4}(0.017 \mathrm{~g}), \mathrm{NH}_{4} \mathrm{NO}_{3}(0.4 \mathrm{~g}), \mathrm{KH}_{2} \mathrm{PO}_{4}(0.003 \mathrm{~g})$, $\mathrm{MgSO}_{4} .7 \mathrm{H}_{2} \mathrm{O}(0.05 \mathrm{~g})$ as described by Ekundayo et al., (2012) was prepared containing $0.1 \%$ of refinery effluents and was sterilized by autoclaving at $121^{\circ} \mathrm{C}$ for 15 minutes. Ten millilitres of MSM was transferred into fifteen test tubes and $0.2 \mathrm{ml}$ of PDB grown isolates was transferred into fourteen tubes of the sterile MSM, mixed properly and incubated at room temperature $\left(25 \pm 2^{\circ} \mathrm{C}\right)$ for 8 days. Test tube of MSM with $0.1 \%$ refinery effluent (without inoculum) served as control. The tubes were monitored for growth indicated by the level of turbidity, dry weight and change in $\mathrm{pH}$ of the medium.

Molecular Identification of Fungi Isolates: Genomic DNA was extracted at DNA Labs Kaduna, using Accuprep genomic extraction kit method. This was carried out in accordance with the manufacturer's procedure. Amplification of Internal Transcribed Spacer (ITS1) region of fungi isolates described by Raja et al. (2017) using PCR was used to identify the fungi isolates. The primers ITS1F (5 CTTGGTCATTTAGAGGAAGTAA- $3^{1}$ ) and ITS4R $\left(5^{1}\right.$-TCCTCCGCTTATTGATATGC $\left.-3^{1}\right)$ reported by Travis et al. (2000) was used for the amplification in a 9600 Thermocycler. $50 \mu \mathrm{L}$ PCR mixtures contain: $0.5 \mu \mathrm{M}$ of each primer, $200 \mu \mathrm{M}$ dNTPs, $3 \mathrm{mM} \mathrm{MgCl}_{2}$, $\mathrm{PCR}$ reaction buffer $(50 \mathrm{mM} \mathrm{KCl}, 20 \mathrm{mM}$ Tris- $\mathrm{HCl}$ at pH 8.0), 1U Taq DNA polymerase (Promega, USA), and $2 \mu \mathrm{l}$ of template DNA. After the PCR amplification, $5 \mu$ l of the PCR mix was analyzed in 1\% agarose gels containing $1 \mu \mathrm{g} / \mathrm{ml}$ of ethidium bromide. The electrophoresis was done at $100 \mathrm{~V}$ for $35 \mathrm{~min}$, observed under UV light on a transilluminator and photographed with the gel electrophoresis image system (Gel-Doc). 100bp ladder was used as molecular weight marker and loading dye $(0.25 \%$ xylene cyalon, $0.25 \%$ bromophenol blue, $30 \%$ glycerol and $1 \mathrm{mM}$ EDTA) was employed. The nucleotide sequences of the Internal Transcribed Spacer (ITS1) region of fungi isolates was subjected to Basic Local Alignment Search Tool (BLAST) analysis for comparison of nucleotide sequence query against public nucleotide sequence database (Rolf et al., 2018).

Bioremediation Study: Fungi which showed maximum growth during the screening test was molecularly characterized and selected for bioremediation study. Fungi consortia were prepared for bioremediation study after the screening test. The control was without fungi inoculum. Bioremediation study was carried out in accordance with the methods of Vanishree et al. (2014) by monitoring the following parameters: fungi counts, $\mathrm{pH}, \mathrm{CO}_{2}$ evolution, oil and grease, phenol, heavy metals $(\mathrm{Cd}, \mathrm{Pb}$ and $\mathrm{Ni})$ of the amended effluents. A total of 16 conical flasks (250 $\mathrm{ml}$ ) were used in duplicate, $4 \mathrm{ml}$ of each consortium was inoculated into $200 \mathrm{ml}$ of previously sterilized refinery effluent supplemented with mineral salt media. The samples were incubated at room temperature at $150 \mathrm{rpm}$ for 28 days and were analyzed at an interval of 7 days for a period of four weeks. Fungi count was carried out using Neubauer chamber 
(hemocytometer) where $0.2 \mathrm{ml}$ of the remediating medium was taken on a weekly basis and observed using $x 40$ objectives of the light microscope. The $\mathrm{pH}$ of the medium was also determined on a weekly basis using a pH meter. The method described by Onwumere and Ndibe (2017) was adopted for the determination of carbon (IV) oxide evolution. Small glass vials containing $10 \mathrm{ml}$ of $0.5 \mathrm{M}$ Sodium hydroxide $(\mathrm{NaOH})$ to trap the evolved $\mathrm{CO}_{2}$ were put in the enclosed conical flask containing the medium but made to hang inside. After 7 days of introducing the $\mathrm{NaOH}$, the glass vial was removed and the $\mathrm{CO}_{2}$ trapped in $\mathrm{NaOH}$ was determined titrimetrically. The residual alkali was titrated against $0.1 \mathrm{M} \mathrm{HCI}$ using phenolphthalein as indicator and $\mathrm{CO}_{2}$ evolved was then calculated. This was also done for day 14, 21 and 28. The amount of $\mathrm{CO}_{2}$ evolved was then converted into $\mu \mathrm{g} \mathrm{CO}_{2}$ day $^{-1}$. A Petrosense Portable (PHI-100) device was used to determine the phenol content of samples. The Partition-Gravimetric method described by Machido et al. (2014) was adopted for the analysis of oil and grease. Fifty millilitres $(50 \mathrm{ml})$ of each sample was acidified to $\mathrm{pH} 2.0$ using $5 \mathrm{ml}$ of hydrochloric acid, shaken vigorously for three minutes. The sample was transferred into a separating funnel held by a retort stand, and then $15 \mathrm{ml}$ of hexane was added to the sample which separated the content into layers of oil, grease and water. The oil and grease content was calculated using the formula:

Where $\mathrm{O} \& \mathrm{G}=$ Oil and grease $(\mathrm{mg} / \mathrm{l}), \mathrm{V}=$ volume of sample, $\mathrm{FW}=$ final weight, $\mathrm{IW}=$ initial weight

$$
O \& G=\frac{F W(m g)-I W(m g) \times 1000}{V(m l)}
$$

The concentrations of heavy metals (lead, nickel and cadmium) in the samples were analyzed using the fast sequential atomic absorption spectrophotometer (AAS) following the modified method of APHA (1998). Fifty millilitres $(50 \mathrm{ml})$ of each sample was digested in a beaker by adding $5 \mathrm{ml}$ of nitric acid, heated to almost dryness and topped up to $100 \mathrm{ml}$ with distilled water. The digested samples were filtered to remove any insoluble materials that could clog the atomizer. The filtrate was then analyzed for heavy metals using the AAS.

Statistical Analysis: Descriptive statistics in the form of tables were used to represent the data obtained from this study. Means were analyzed and compared using Analysis of Variance (ANOVA) test. Any significant difference was analyzed using a Post-test; Fisher's Least Significant Difference Test. Correlation analysis was carried out on the parameters. All analyses were carried at P-Value of 0.05 .

\section{RESULTS AND DISCUSSION}

Morphological Characteristics of the Fungi Isolates: A total of 14 fungi species were isolated. Colonial and microscopic characteristics showed that the probable fungi in the samples from the four sampling sites were Chrysosporium tropicum, Aureobasidium pullulans, Arthrographis kalrae, Epidermophyton flocosum, Aspergillus flavus, Madurella grisea, Coccidioides immitis, Penicillium marneffei, Mucor sp, Trichophyton mentagrophytes, Aspergillus niger, Rhizopus oryzae, Trichoderma sp and Pseudallescheria boydii.

Table 1: Screening Test of Fungi Isolated for growth in Refinery Effluents

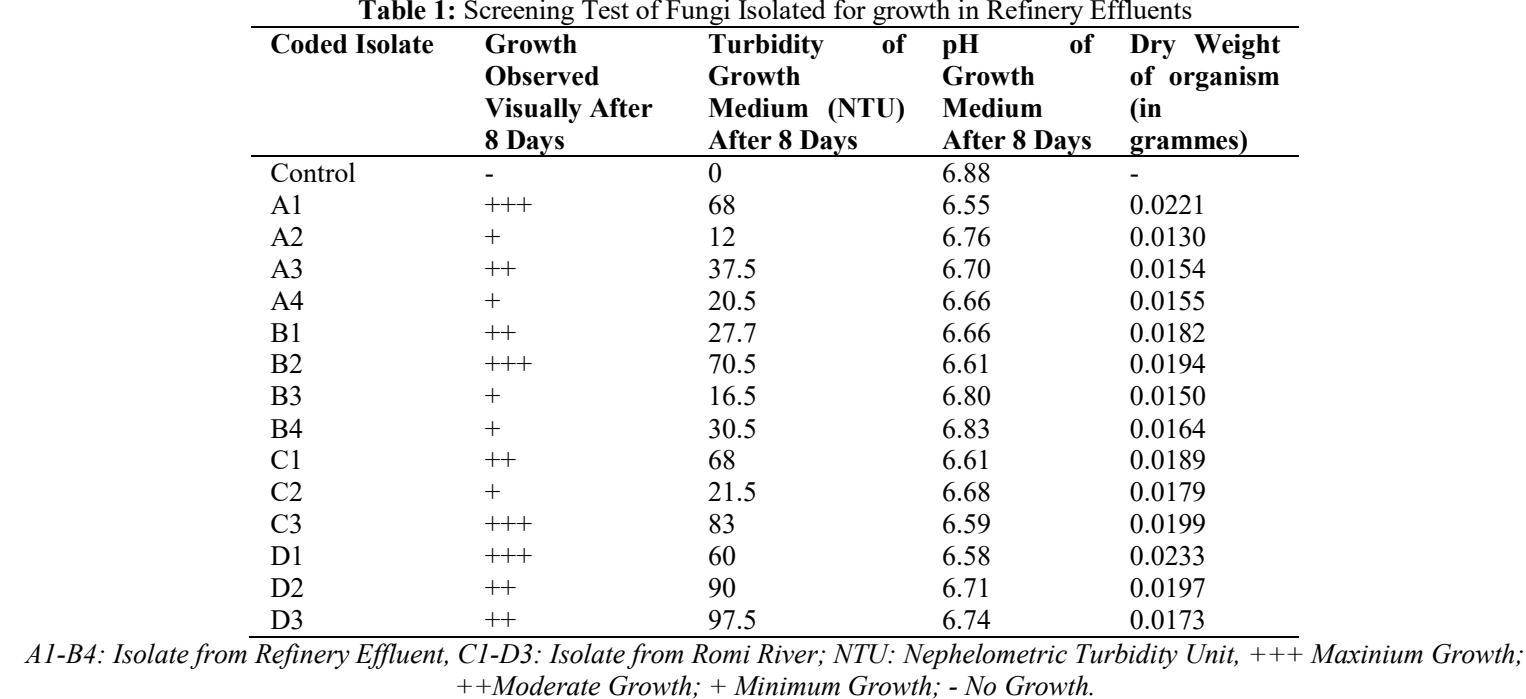

Screening Test for the Fungi Isolates: Turbidity and organisms were observed after 8 days. Isolates A1, C3, $\mathrm{pH}$ of growth medium as well as dry weight of D1 and D2 showed maximum growth and their 
turbidity were $68,83,60$ and 90 NTU respectively (Table 1). The $\mathrm{pH}$ of the growth medium after 8 days was slightly acidic $(6.55-6.71)$. The dry weights ranged from $0.0197-0.0233$.

Molecular Identification of the Fungi Isolates for Bioremediation Studies: Based on the screening of fungi isolates, four isolates with maximum bioremediation potential were selected and molecularly identified. Molecular identification revealed that the fungi isolates for bioremediation studies were Chrysosporium tropicum (A1), Aspergillus flavus (C3), Aspergillus niger (D1) and Rhizopus oryzae (D2).

Bioremediation Study: The first fungi consortium used for the bioremediation study consisted of Chrysoporium tropicum and Aspergillus niger $(\mathrm{A} 1+\mathrm{D} 1)$, the second consortium consisted of Aspergillus flavus and Rhizopus oryzae (C3+D2), the third consortium consisted of Chrysosporium tropicum, Aspergillus niger, Aspergillus flavus and Rhizopus oryzae (A1+D1+C3+D2). The fourth consortium served as control (without fungi inoculum). The results of bioremediation studies are presented in Table 2. The fungi count increased in the first two weeks and then decreased. Analysis of variance showed that there was a significant difference $(\mathrm{P}<0.05)$ between the fungi counts during the four weeks of bioremediation. Fungi counts at week 1 and 2 varied significantly $(\mathrm{P}<0.05)$ with that of week 4 . There was no correlation between the fungi counts and physicochemical parameters during the bioremediation studies (Table 3). The $\mathrm{pH}$ of the medium throughout the period of bioremediation studies remained slightly acidic.

This finding is in agreement with the report of Uzoekwe and Oghosanine (2011) who recorded a $\mathrm{pH}$ of 6.5 - 8.5 from Warri Refinery effluent during bioremediation study. The observed $\mathrm{pH}$ during the bioremediation ranged from $6.56-6.90$. In agreement to this study, Khaled et al. (2016) reported that optimized conditions of $\mathrm{pH} 6.0-7.0$ greatly influenced the efficiency of bioremediation. The investigators concluded that optimization of the culture conditions of the medium caused the consortium to degrade diesel in the polluted soil, $12.5 \%(\mathrm{v} / \mathrm{w})$ after 35 days of incubation.

The result showed that there was significant difference $(\mathrm{P}<0.05)$ between the $\mathrm{pH}$ during the four weeks of bioremediation. $\mathrm{pH}$ at week 1 differed significantly from week 3 and 4 , and $\mathrm{pH}$ at week 2 differed significantly from week 4 (Table 3 ). With the exception of fungal counts, phenol and cadmium, $\mathrm{pH}$ correlated with other parameters during bioremediation (Table 4). There was a strong positive correlation between $\mathrm{pH}$ and $\mathrm{CO}_{2}$ (0.954). $\mathrm{pH}$ correlated negatively with oil and grease (-0.995), lead $(-0.954)$ and nickel (-0.998), (Table 4). Carbon (IV) oxide evolution increased progressively during the period of bioremediation. The highest $\mathrm{CO}_{2}$ evolved was observed at week 4 in the medium containing the four fungi consortium.

Table 2: Bioremediation Study

\begin{tabular}{|c|c|c|c|c|c|c|c|c|}
\hline ISOLATE CODES & PARAME & ERS & & & & & & \\
\hline WEEK 1 & $\begin{array}{l}\text { Fungi } \\
\text { Counts } \\
\text { (cfiuml) }\end{array}$ & $\mathrm{pH}$ & $\begin{array}{l}\mathrm{CO}_{2} \\
\text { Evolved ( } \mu \mathrm{g} \\
\mathrm{CO}_{2} \text { day }\end{array}$ & $\begin{array}{l}\text { Oil and } \\
\text { Grease } \\
(\mathrm{mg} / \mathrm{L})\end{array}$ & $\begin{array}{l}\text { Phenol } \\
\text { (ppm) }\end{array}$ & $\begin{array}{l}\text { Lead } \\
(\mathrm{mg} / \mathrm{L})\end{array}$ & $\begin{array}{l}\text { Cadmium } \\
(\mathrm{mg} / \mathrm{L})\end{array}$ & $\begin{array}{l}\text { Nickel } \\
(\mathrm{mg} / \mathrm{L})\end{array}$ \\
\hline Control & 0 & 6.90 & 92.8 & 700 & 1.90 & 0.263 & 0.433 & 0.142 \\
\hline $\mathrm{Al}+\mathrm{Dl}$ & $0.56 \times 10^{6}$ & 6.68 & 110.3 & 650 & 1.55 & 0.252 & 0.421 & 0.140 \\
\hline $\mathrm{C} 3+\mathrm{D} 2$ & $0.99 \times 10^{6}$ & 6.56 & 118.0 & 667 & 1.28 & 0.226 & 0.431 & 0.142 \\
\hline $\begin{array}{l}\mathrm{A} 1+\mathrm{D} 1+\mathrm{C} 3+\mathrm{D} 2 \\
\text { WEEK 2 }\end{array}$ & $0.98 \times 10^{6}$ & 6.40 & 124.5 & 601 & 1.60 & 0.241 & 0.422 & 0.139 \\
\hline Control & 0 & 6.90 & 93.5 & 700 & 1.90 & 0.263 & 0.433 & 0.142 \\
\hline $\mathrm{Al}+\mathrm{Dl}$ & $1.3 \times 10^{6}$ & 6.68 & 116.7 & 631 & 1.43 & 0.252 & 0.414 & 0.131 \\
\hline $\mathrm{C} 3+\mathrm{D} 2$ & $1.6 \times 10^{6}$ & 6.60 & 119.0 & 645 & 1.12 & 0.225 & 0.324 & 0.123 \\
\hline $\begin{array}{l}\mathrm{A} 1+\mathrm{D} 1+\mathrm{C} 3+\mathrm{D} 2 \\
\text { WEEK 3 }\end{array}$ & $1.9 \times 10^{6}$ & 6.58 & 190.6 & 584 & 1.32 & 0.231 & 0.311 & 0.131 \\
\hline Control & 0 & 6.90 & 92.7 & 700 & 1.90 & 0.263 & 0.433 & 0.142 \\
\hline $\mathrm{Al}+\mathrm{Dl}$ & $1.1 \times 10^{6}$ & 6.73 & 308.1 & 620 & 1.42 & 0.250 & 0.400 & 0.077 \\
\hline $\mathrm{C} 3+\mathrm{D} 2$ & $1.3 \times 10^{6}$ & 6.76 & 213.9 & 602 & 1.10 & 0.153 & 0.313 & 0.123 \\
\hline $\begin{array}{l}\mathrm{A} 1+\mathrm{D} 1+\mathrm{C} 3+\mathrm{D} 2 \\
\text { WEEK } 4\end{array}$ & $1.5 \times 10^{6}$ & 6.75 & 421.2 & 581 & 1.01 & 0.191 & 0.310 & 0.120 \\
\hline Control & 0 & 6.90 & 94.6 & 700 & 1.90 & 0.263 & 0.433 & 0.142 \\
\hline$+\mathrm{Dl}$ & $1.0 \times 10^{6}$ & 6.82 & 455.8 & 596 & 1.40 & 0.105 & 0.367 & 0.073 \\
\hline $\mathrm{C} 3+\mathrm{D} 2$ & $1.2 \times 10^{6}$ & 6.81 & 407.5 & 600 & 1.10 & 0.095 & 0.302 & 0.116 \\
\hline$+\mathrm{C} 3+\mathrm{D} 2$ & $1.4 \times 10^{6}$ & 6.86 & 679.6 & 555 & 1.00 & 0.144 & 0.300 & 0.100 \\
\hline
\end{tabular}

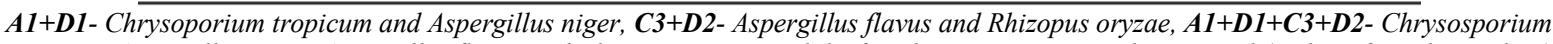
tropicum, Aspergillus niger, Aspergillus flavus and Rhizopus oryzae and the fourth consortium served as control (without fungal inoculum),

$\boldsymbol{c} f \mathbf{u} / \mathbf{m l}$ - colony forming unit, $\boldsymbol{\mu g} \mathrm{CO}_{2}$ day $^{-1}$ - microgram of carbon dioxide per day, $\mathbf{m g} / \mathbf{L}$ - Milligram per Liter, ppm- part per million 
Table 3: Microbiological and Physicochemical Parameters

\begin{tabular}{|c|c|c|c|c|c|c|c|c|}
\hline & $\begin{array}{l}\text { Fungi } \\
\text { counts }\end{array}$ & $p$ & $\begin{array}{l}\text { Carbon } \\
\text { (IV) oxide }\end{array}$ & Gre & & Lead & & \\
\hline & & & 117.6 & $639.333^{2}$ & & & & \\
\hline & & & 105 & & & & & \\
\hline & & & 314 & & & & & \\
\hline Week 4 & $1.200 \times 10$ & $6.830^{\circ}$ & $514.300^{\circ}$ & $667^{\mathrm{z}}$ & $1.167^{\mathrm{a}}$ & 0.148 & $0.323^{a}$ & $0.096^{b}$ \\
\hline
\end{tabular}

Means in the same column which do not share a letter are significantly different

Table 4. Correlation of microbiological and physicochemical parameters during bioremediation studies

\begin{tabular}{|c|c|c|c|c|c|c|c|}
\hline & $\begin{array}{l}\text { Fungi } \\
\text { Count }\end{array}$ & $\mathrm{pH}$ & $\mathrm{CO}_{2}$ & $\begin{array}{l}\text { Oil and } \\
\text { Grease }\end{array}$ & Phenol & Lead & Cadmium \\
\hline$\overline{\mathrm{pH}}$ & 0.247 & & & & & & \\
\hline $\mathrm{CO}_{2}$ & -0.033 & $0.954^{8}$ & & & & & \\
\hline Oil and Grease & -0.334 & $-0.995^{*}$ & -0.929 & & & & \\
\hline Phenol & -0.565 & -0.924 & -0.767 & 0.943 & & & \\
\hline Lead & -0.017 & $-0.954^{*}$ & $-0.995^{*}$ & 0.938 & 0.772 & & \\
\hline Cadmium & -0.693 & -0.869 & -0.696 & 0.911 & $0.969^{\circ}$ & 0.724 & \\
\hline Nickel & -0.265 & $-0.998^{*}$ & -0.940 & $0.992^{8}$ & 0.938 & 0.937 & 0.875 \\
\hline
\end{tabular}

The result showed that there was significant difference $(\mathrm{P}<0.05)$ between the carbon (IV) oxide evolved during the four weeks of bioremediation. The amount of $\mathrm{CO}_{2}$ evolved at week 1 was significantly different $(\mathrm{P}<0.05)$ from that of week 2,3 and $4 . \mathrm{CO}_{2}$ evolution at week 2 differed significantly $(\mathrm{P}<0.05)$ from that of week 3 and 4 (Table 3). There was a negative correlation between $\mathrm{CO}_{2}$ and lead with a coefficient of -0.995 (Table 4). Oil and grease content decreased in all treatments as compared to the control during the period of bioremediation particularly at week 4 in the treatment involving the four fungi consortium. Analysis of variance showed that there was no significant difference $(\mathrm{P}>0.05)$ between the oil and grease content in the medium during the four weeks of bioremediation studies. Oil and grease correlated positively with nickel with a coefficient 0.992 (Table 4). The values recorded for heavy metals indicate that they are ubiquitous in the environment especially lead, with diverse pollution sources. According to Holliger et al. (1997), prominent health and safety experts expressed concern about adding tetraethyl lead to gasoline. An estimated 7 million tons of lead burned in gasoline remain in the soil, air, water and bodies of living organisms. Most cadmium and nickel compounds are carcinogenic; long exposure may cause kidney, liver and nerve damage. The heavy metal results obtained in this study were similar to the findings of Ubwa et al. (2013) on the assessment of surface water pollution, who obtained values of cadmium and lead as $4.25(\mathrm{mg} / \mathrm{L})$ and $7.50(\mathrm{mg} / \mathrm{L})$ respectively which was above the specified limit of WHO. Heavy metals are one of the most persistent pollutants present in water. Akpor and Muchie (2010) reported that unlike other pollutants, heavy metals are difficult to degrade, but can accumulate throughout the food chain, producing potential human health risks and ecological disturbances. During bioremediation, there was a noticeable decrease in the phenol, lead, cadmium and nickel content in the medium. Analysis of variance showed that there was no significant difference $(\mathrm{P}>0.05)$ between the phenol, lead and cadmium content in the medium during the four weeks of bioremediation studies. There was a positive correlation between phenol and cadmium contents of the samples with a coefficient of 0.969 (Table 4).The nickel content differed significantly $(\mathrm{P}<0.05)$ with respect to the period of the bioremediation studies; nickel content at week 1 was significantly different $(\mathrm{P}<0.05)$ from that of week 3 and 4 (Table 3). The consortium of fungi (Chrysosporium tropicum, Aspergillus flavus, Aspergillus niger and Rhizopus oryzae) identified in this study exhibited bioremediation potentials. There was a general decrease in the level of lead $(40.2 \%)$, phenol (37.5\%), cadmium (28.9\%), nickel $(28.1 \%)$ and oil and grease $(7.65 \%)$ during the period of bioremediation study, which is an indication that the fungal consortium was effective in the bioremediation of refinery effluent. Kumar et al. (2014) observed that Aspergillus sp and Chrysosporium sp could reduce the concentration of heavy metals from effluent. Arao et al. (2010) also observed that with the increasing metal concentration, fungi can increase the rate of heavy metal removal by increasing mobilization of metal ions. The researchers proposed that metals are mobilized via several mechanisms, including acidolysis, complexolysis and reductive mobilization. Sabah et al. (2016) reported on the ability of Aspergillus niger to biodegrade refinery effluent and petroleum hydrocarbons. They observed that, $A$. niger was effective in remediating refinery effluent to acceptable limits for contaminants. Also, Ezeonuegbu et al. (2016) reported the use of fungi to remediate and bioaccumulate some metals from refinery wastewater and documented that, A. flavus, $A$. niger, A. fumigatis and Penicillium sp. in consortium 
could be employed to remediate sites contaminated with $\mathrm{Pb}, \mathrm{Ni}$ and $\mathrm{Cd}$ based on their ability to remove or bioaccumulate these metals. Using a consortia of pure strain and mutant strain (subjected to 5, 10, and 15 minutes of irradiation) of Penicillium janthinellium and Pseudomanas aeruginosa, Bako et al. (2008) studied the potential of these strains to degrade crude oil in river Kaduna effluent after two weeks of incubation. They reported lower levels of oil, grease and phenol concentration in all but two consortia when compared to FEPA (Federal Environmental Protection Agency) limits. The result of this study further revealed that the third consortium consisting of the four fungi species showed the most efficient capability in bioremediating the refinery effluent, particularly in reducing the concentrations of lead $(40.2 \%)$, phenol (37.5\%), cadmium (28.9\%), nickel $(28.1 \%)$ and oil and grease $(7.65 \%)$ (Table 2 ).

Conclusion: This study showed that a total of fourteen different fungi species were isolated from the effluent discharge of Kaduna Refinery and Petrochemical Company (KRPC) and Romi River. Chrysosporium tropicum, Aspergillus flavus, Aspergillus niger and Rhizopus oryzae showed potential for bioremediation. Consortia of the fungi isolates from the refinery effluent and Romi River were effective in the bioremediation of refinery effluent. Therefore, KRPC should adopt bioremediation as one of the techniques in treating effluents before being discharged into receiving water bodies.

\section{REFERENCES}

Adenuga, AO; Ogujiuba, K.; Ohuche, FK. (2006). Sustainability of the environment and water pollution in Nigeria: Problems, management and policy options. Global Journal of Environmental Research, 15: 49-59.

Akpor, OB; Muchie, M. (2010). Remediation of heavy metals in drinking water and wastewater treatment systems: Processes and applications. International Journal of Physical Sciences, 5(12):1807-1817.

APHA. (1998). Standard methods for the examination of water and wastewater. 20th Edition, American Public Health Association, American Water Works Association and Water Environmental Federation, Washington DC USA.

Arao, T; Ishikawa, S; Murakam, IM. (2010). Heavy metal contamination of agricultural soil and counter measures in Japan. Paddy and Water Environment, 8(3): 247-257.
Ashoka, C; Geetha, MS; Sullia, SB. (2002). Bioleaching of composite textile dye effluent using bacterial consortia. Asian Journal of Microbial Biotechnology Environmental Science, 4: $65-68$.

Aust, SD; Swaner, PR; Stahl, JD. (2003). Detoxification and metabolism of chemicals by white-rot fungi. Pesticide decontamination and detoxification. Oxford University Press, Washington, D.C, pp 3-14.

Bako, SP; Chukwunonso, D; Adamu, AK. (2008). Bioremediation of refinery effluent by strains of Pseudomonas Aerugenosa and Penicillium Janthinellium. Applied Ecology and Environmental Research, 6(3): 46-60.

Basorun, JO; Olamiju, IO. (2013). Environmental pollution and refinery operations in an oil producing region of Nigeria: A focus on Warri Petrochemical Company. Journal of Environmental Science, Toxicology and Food Technology, 2: 18-23.

Ekundayo, FO; Olukunle, OF; Ekundayo, EA. (2012). Biodegradation of Bonny light crude oil by locally isolated fungi from oil contaminated soils in Akure, Ondo State. Malaysian Journal of Microbiology, 8(1): $42-46$.

Ezeonuegbu, BA; Machido, DA; Yakubu, SE. (2016). Capacity of fungal genera isolated from refinery effluent to remove and bioaccumulate lead, nickel and cadmium from refinery waste. International Journal of Science and Technology, 3(6): 47-52.

Gadd, GM. (2010). Metals, minerals and microbes: geomicrobiology and bioremediation. Microbiology, 156: 609-643.

Hadibarata, T. and Tachibana, S. (2009). Degradation of crude oil by fungi pre-grown on wood meal. Interdisciplinary studies on environmental Chemistry. Journal of Environmental Research, pp. 317-322.

Hakeem, AS; Bhatnagar, S. (2010). Heavy metal reduction of pulp and paper mill effluent by indigenous microbes. Asian Journal of Experimental and Biological Sciences, 1(1): 201203.

Holliger, C; Gaspard, S; Glod, G. (1997). Contaminated environments in the subsurface and 
bioremediation of organic contaminants, FEMS Microbiology Reviews, 20(4): 517-523.

Idowu, FC; Ijah UJJ (2017). Biormediation of diesel oil polluted soil following amendment with fungal consortium. Journal of Science, Technology Mathematics and Education, (JOSTMED) 33:1626.

Khaled, MG; Saleh, AM; Majid, AA. (2016). Bioremediation of diesel fuel by fungal consortium using statistical experimental designs. Journal of Environmental Study 25. (1) 42493.

Kumar, A; Singh, P; Dhir, B; Sharma, KA; Mehta, D. (2014). Potential of some fungal and bacterial species in bioremediation of heavy metals. Journal of Nuclear Physics, Material Sciences, Radiation and Applications, 1(2):213-223.

Machido, DA; Yakubu, SE; Ezeonuegbu, BA. (2014). Composition of fungal flora in raw refinery effluent, effluent retention pond and a treated effluent recipient river. Journal of Applied Science and Environmental Management, 18(4): 592-596.

Mansur, MME; Arias, JL; Copa-Patino, M; Flardh, M; Gonzalez AE. (2003): The white-rot fungus Pleurotus ostreatus secretes laccase isozymes with different substrate specificities. Mycologia, 95: 1013-1020.

Obire, O; Anyanwu, EC; Okigbo, RN. (2008). Saprophytic and crude oil-degrading fungi from cow dung and poultry droppings as bioremediating agents. International Journal of Agricultural Technology, 4:81-89.

Okougbo, AE; Bello, YM; De, N. (2016). Biodegradation of crude oil, refinery effluent and some petroleum components by Penicillium Sp. and Mortierella Sp. isolated from oil contaminated soil in auto mechanic workshops. International Conference on African Development Issues, pp: 407-412.

Onwumere, GB; Ndibe, TO. (2017). Comparative Study of Leaf Litter Decomposition of Two Exotic Tree Species in Savanna Ecological Zone, Afaka, Kaduna State, Nigeria. Nig. J. Microbiol. 31 (2): 3996 - 4009.
Raja, HA; Miller, AN; Pearce, CJ; Oberlies, NH. (2017). Fungal identification using molecular tools: A primer for the natural products research community. Journal of Natural Production, 80: 756-770.

Rolf, HN; Karl, HL; Andy, FS; Johan, BP; Thomas, SJ; Dmitry, S; Peter, K.; Kathryn, P; Frank, OG; Leho, T. (2018). The UNITE database for molecular identification of fungi: handling dark taxa and parallel taxonomic classifications. Nucleic Acids Research, 47, Pp: D259-D264, https://doi.org/10.1093/nar/gky1022.

Sabah, G; Jatau, ED; Whong, C. (2016). Assessment of biodegredation ability of Aspergillus niger isolated from mechanic workshops soil on refinery effluent and petroleum hydrocarbons. International Journal of Science and Research Publications. 6(3): 381-389.

Thipeswamy, B; Shivakumar, CK; Krishnapa, M. (2012): Bioaccumulation potentials of Aspergillus niger and Aspergillus flavus for heavy metal removal from paper mill effluent. Journal of Environmental Biology, 33: 1063-1068.

Ubwa, ST; Atoo, GH; Offem, JO; Abah, J; Asemave, K. (2013). An assessment of surface water pollution status around Gboko abattoir. African Journal of Pure and Applied Chemistry, 7(3): 131-138.

Ugya, AY; Tahir, SM; Imam, TS. (2015). The Efficiency of Pistia Stratiotes in the phytoremediation of Romi Stream: A case study of Kaduna Refinery and Petrochemical Company polluted stream. Inter. J Health Sci. Resource. 5(2):492-497.

Uzoekwe, SA; Oghosanine, FA. (2011). The effect of refinery and petrochemical effluent on water quality of Ubeji Creek, Warri, Southern Nigeria. Ethiopian J. Environ. Stud. Manag. 4(2): 107108.

Vanishree, M; Thatheyus, AJ; Ramya, D. (2014). Biodegradation of petrol using Aspergillus species. Annual Res. Rev. Biol. 4(6): 914-923. 